\title{
Agency of the Witches and Language Play in Shakespeare's Macbeth
}

\author{
Dhurjjati Sarma ${ }^{1}$ \\ https://orcid.org/0000-0002-3808-0152 \\ ${ }^{1}$ Gauhati University, Assam, India
}

\begin{abstract}
This study undertakes an analysis of Shakespeare's Macbeth (1606) and its principal characters vis-à-vis their immediate appeal and identification with the Shakespearean audience during the first-ever performance of the play in the early years of the seventeenth century. The role of the witches (or the weird sisters) in orchestrating the destinies of the characters and also the events of the play by employing their astute and skillful use of language is a significant point of discussion in this study. In this regard, a discussion on the historical aspects of kingship and witchcraft in relation to the then king of England, James I, and on the possible impact of those factors upon the staging of the Shakespearean play Macbeth in the royal court is also carried out here. The study argues that the binaries of good and evil or light and darkness are relative categories that often feed into each other. Equivocation, as a device of language play, is analyzed here both as part of the witches' machinations within the play and as a subterfuge for political gains by humans in the world outside it. These two worlds seem to merge into each other within the narrative of the play and thus appear before the reader/audience with all their inherent complexities and imperfections. Towards the end of this study, a brief historical overview of the refashioning of Shakespeare through adaptations and reworkings in foreign locations, particularly in India, is also provided to emphasize the allegorical and multivalent nature of his plays.
\end{abstract}

Keywords: Shakespeare, Macbeth, James I, witchcraft, equivocation

\section{Introduction}

William Shakespeare's play The Tragedie of Macbeth was first performed during the summer of the year 1606 on the occasion of the visit of the king of Denmark to England. It was as part of the festive reception accorded to the visiting king that the King's Men, Shakespeare's company of actors, presented this new tragedy, which was, as we shall see, also a tribute to James I, the newly installed king of England and Scotland. The significance and popularity of the

This open-access work is licensed under a Creative Commons Attribution Noncommercial 4.0 International License. For more information visit https://creativecommons.org/licenses/by-nc/4.0/ 
play lie not only in its being one of the big four tragedies written by Shakespeare but also for its unmistakable association with the socio-political currents of the time when it was written and first performed. Published seven years after the death of Shakespeare in the First Folio of 1623, the play is the "shortest of Shakespeare's tragedies, without diversions or subplots" (Bevington) with a total of 2477 lines. It was a play that Shakespeare composed within a very short time and, unlike most of his other tragedies, the narrative is fast-paced and moves swiftly towards the climax.

The theme of the supernatural has played a determining role in framing the many interpretations of the play (Maguire; Smith). Coupled with it are the themes of ambition and treachery that have been used to define the human actions within the play (Bloom; Russell). One of the recurrent features of traditional Shakespearean criticism has been that, owing to the universal appeal and outreach, most of his plays are often explained as compositions narrativizing human thoughts and actions across all cultures (Bate; Kott). However, under the influence of the twin schools of New Historicism and Cultural Materialism, the study of early modern poets and playwrights like William Shakespeare got a new lease of life. As a critical approach to literature and culture developed primarily through the works of Michel Foucault and Stephen Greenblatt, "New Historicism reopened the interpretation of literature to the social, political, and historical milieu that produced it" ("New Historicism"). On the other hand, Cultural Materialism, as a literary-critical practice, emphasized "the historical and material conditions of the production and reception of texts" (Bertens).

What these schools have done with the study of Shakespeare is to renew and reactivate interest into the social, political, and historical contexts and events that motivated and provided the much-needed impetus for the composition of his plays. Based on this understanding, the 
present study will be an attempt to locate the narrative and characters of the play Macbeth, particularly the all-important figures of the witches (or the weird sisters), as responding to the immediate sensibilities of the Shakespearean audience for whom there would have been striking resonances within the play vis-a-vis the politically turbulent times that they were living through. ${ }^{1}$ This essay will be referring to the speeches of the witches as they appear at crucial moments throughout the play and shall analyze the connotations of their utterances and how the human characters in the play interpret their prophecies and mold their actions to their purposes.

\section{Analysis and Discussion}

The agency of the witches is emphasized by Shakespeare right at the beginning of the play when they are given the opening words: "When shall we three meet again?/ In thunder, lightning, or in rain?" (I.I.1-2). Now this opening scene is interesting because it does not apparently add to the dramatic action of the play; however, what it actually does is to give the audience a hint of the things that are presently happening and a premonition of what is to come: "When the hurlyburly's done,/ When the battle's lost and won./... Upon the heath./ There to meet with Macbeth" (I.I.3-8). By referring to the battle that is simultaneously lost and won, and the necessity to confront Macbeth on the part of the witches, there is an early hint at the double-

edged and antithetical nature of events and actions which are to follow in the course of the play. ${ }^{2}$ The witches' cry in unison_- "Fair is foul, and foul is fair:/ Hover through the fog and filthy air" (I.I.12) - strengthens this premonition that if good can prevail over evil, the same good can degenerate towards the evil; such has been the times and the disposition of human character and action, and the witches have declared it triumphantly at the very outset of the play. 
The witches exercise their agency through a collective engagement with highly cryptic wordplay that leaves the characters and audience of the play alike in confusion and bewilderment. For Shakespeare, the introduction of the witches in the very first scene of the play operates in two ways: on the one hand, it provides an early indication of the witches' role in the unfolding of the dramatic narrative, and, on the other hand, it places them upon a vantage ground from which they would observe and direct the actions of the characters. They seem to inhabit a space that is both inside and outside the narrative confines of the play — they appear at significant moments within the play, even though their presence is felt throughout the whole duration of its enactment.

The second scene of the first act opens with reports of a battle taking place with Macbeth and Banquo, generals to Duncan, the king of Scotland, engaged in combat against the combined forces of rebel Macdonwald, the invading Norwegian lord, and the traitorous Thane of Cawdor. Messengers bring tidings to the king about the courage and valor shown by Macbeth in ruthlessly crushing the rebellion and murdering the rebel general, and the king, mightily impressed, rightfully punishes the incumbent Thane of Cawdor and strips him of his title to be bestowed upon Macbeth. The scene ends with Duncan pronouncing, "What he hath lost, noble Macbeth hath won" (I.II.69), terribly reminiscent of what the witches had earlier prophesied. And Duncan himself would not have known then what his pronouncement would lead to as far as his own life is concerned.

Scene III moves to the most critical point at the beginning of the play where the weird sisters appear again, "hand in hand" (I.III.32), who have assembled to meet Macbeth as the latter along with Banquo is returning victorious from the battle. It is as if the witches are also playing a role of directing the attention of the audience towards the entry of Macbeth and Banquo in 
person for the first time in the play. And interestingly, the first line that Macbeth utters is: "So foul and fair a day I have not seen" (I.III.38), again referring back to the united cry of the witches earlier. On this parallel between the weird sisters and Macbeth established by Shakespeare, it is commented that "although Macbeth has not yet set eyes upon these hags, the connection is already established between his soul and them. Their spells have already wrought upon his blood" (Dowden, quoted in Muir ed., Macbeth, 14). Therefore, one can see that not only Macbeth but also Duncan as in the previous scene, is only reiterating what has already been pronounced by the witches. However, those more fateful and fatal words have not yet dropped from their lips.

It is through Banquo that one gets an objective insight into the physical attributes of the witches. The contorted and cadaverous appearance of the witches is made apparent by his remark upon seeing them blocking their way: "What are these,/ So wither'd and so wild in their attire,/ That look not like th'inhabitants o'th'earth,/ And yet are on't? Live you? or are you aught/ That man may question? You seem to understand me,/ By each at once her choppy finger laying/ Upon her skinny lips: you should be woman,/ And yet your beards forbid me to interpret/ That you are so" (I.III.39-47). Banquo here hints at the incongruity of the witches' existence upon this earth despite not seeming so by the virtue of their appearance. One may compare this description with that which appeared in Shakespeare's other play Hamlet concerning the appearance of the deceased king in the form of a ghost. As Horatio similarly questions: "What art thou that usurp'st this time of night,/ Together with that fair and warlike form/ In which the majesty of buried Denmark/ Did sometimes march?" (Hamlet I.I.49-52).

However, unlike the ghost of King Hamlet which disappears silently upon being exhorted to speak, the witches here, as attested by Banquo himself, immediately assert their authority by 
asking him to stay silent, and thus refusing to speak to him and instead of replying directly to Macbeth, and each of them addressing him successively as the "Thane of Glamis" ([I.III.48], which he has been so far), as the "Thane of Cawdor" ([I.III.49], the audience know about it but Macbeth and Banquo do not), and finally as the "King" ([I.III.50], one that would have decisive and disastrous consequences). At this point, the prophecies of the witches could be compared with those of the soothsayers of ancient Greece who were a core component of the Greek tragedies, most notably, King Oedipus. ${ }^{3}$ Therefore, the witches are merely announcing the chain of events across the spectrum of time. Even Banquo, who seemed more composed than Macbeth while confronting the witches, is surprised seeing the latter startle upon hearing these prophecies since he considered them as "[t]hings that do sound so fair" (I.III.52). For Banquo, the language of the witches sounds pretty straightforward and unambiguous, and as such he trusts their abilities to "look into the seeds of time" and "say which grain will grow, and which will not" (I.III.58-59), and thus exhorts them to speak to him in no uncertain terms.

For Banquo, however, the witches only indicate in a suggestive way thereby putting on display their amazing range of language play at their disposal. Banquo shall be "Lesser than Macbeth, and greater./ Not so happy, yet much happier" (I.III.65-66), but what troubles Macbeth here is their prediction for Banquo that: "Thou shalt get kings, though thou be none" (I.III.67) so much so that he calls them "imperfect speakers" (I.III.70) and charges them to reveal the sources of their "strange intelligence" (I.III.76) and the reason why they have confronted him and Banquo "[w]ith such prophetic greeting" (I.III.78). The witches though do not reply to him anymore, and they vanish into thin air much to the bemusement of the two awestruck generals upon the barren heath. 
Keeping the narrative of the play in mind, one can now imagine the impact of the incidents depicted so far upon the minds of Shakespeare's contemporary audience, most importantly, upon James I, the incumbent king of England and Scotland, under whose patronage the play was performed in the first place (Muir xxiii). It was in the knowledge of all those who watched the play that James I, who was originally the king of Scotland (as James VI) before 1603, belonged to a line of kings whose ancestry had been traced back in time to Banquo (Hattaway 108), whose story was recorded in the Scottish section of Raphael Holinshed's Chronicle from which Shakespeare had heavily borrowed for his history plays. Interestingly, in Holinshed, Banquo was recorded as one of the chief allies of Macbeth in his murderous endeavor. On the other hand, in the play, the character of Banquo is projected as one who is firm in his allegiance towards the king and refuses to side with Macbeth. Therefore, by a clever tweaking of the historical evidence, Shakespeare has fashioned a narrative whereby the playwright not only succeeds in assuring James I that he belongs to a line of kings who have been just and rightful but also rekindles the king's interest in the practice of witchcraft and demonology.

While still a king of Scotland, James VI had published a learned treatise on witchcraft in 1597 called the Daemonologie which dealt at length upon the existence of witches in his kingdom and the means to identify and punish them for the dangers they posed to the maintenance of the divine sanctity of kingship and royal authority. ${ }^{4}$ In fact, the king's engagement with the diabolical powers of witchcraft could be traced back to 1589 when his would-be bride Anne of Denmark was forced to take refuge in Oslo when her voyage from Denmark to Scotland was disrupted midway by thunder, lightning, and rain (Greenblatt 346). James believed that these tempests in the sea were raised by the notorious band of witches whose 
network supposedly spanned over from Scotland to Denmark across the seas. He got closely associated with the task of investigating the origins of those witchcraft networks across the sea and land, and thereby undertook a series of witch trials through the 1590s (ibid.). Therefore, Shakespeare's use of the witches as the agents motivating action in the protagonist of his play was sure to have struck a common chord with the king's real-life experiences of dealing with such characters in Scotland.

In addition to the above, there was another event that transpired only a few months before the staging of the play. The event has come to be known as the Gunpowder Plot, ${ }^{5}$ a conspiracy if carried out successfully, would have annihilated the entire ruling house of England. A description of the incident is provided by Greenblatt:

On November 4, 1605, the night before King James I was due to appear in person to open a new session of Parliament, officers of the Crown, alerted some days before by a hint in an anonymous letter, apprehended Guy Fawkes in a cellar that extended beneath the Parliament House. The cellar was loaded with barrels of gunpowder and iron bars, concealed by a load of lumber and coal. Carrying a watch, a fuse, and tinder, Fawkes intended to put into execution a desperate plot devised by a small group of conspirators, embittered by what they perceived as James's unwillingness to extend toleration to Roman Catholics. Under ferocious torture, Fawkes revealed the names of those who had conspired with him to blow up the entire government. The conspirators were hunted down. Those who resisted were killed on the spot; others were arrested and, after a trial that the king watched in secret, were hanged, cut down while they were still alive, slit open, and hewed in quarters. (336) 
Now, for King James I as well as for the audience present at the play, the memories of that event were fresh and clear. Therefore, the references to the rebellion against Duncan at the very outset of the play were surely seen (and possibly also enjoyed with a sigh of relief) in the light of the last-minute escape of the royal house from succumbing to the planned horrors of the Gunpowder Plot. Apart from this, another connection made a more direct bearing upon the play. One of the prime accused in the Gunpowder Plot was a Jesuit priest called Father Henry Garnet who had incidentally written $A$ Treatise of Equivocation in defense of giving out equivocal or inconclusive answers to questions one is under oath to respond truthfully (Huntley; Malloch). There are several instances in the play where characters resort to equivocation to conceal their real intentions or even, as on the part of witches, to deliberately bemuse and bewilder Macbeth towards his own destruction at the end of the play. Equivocation constitutes an important aspect of language play in Shakespeare's Macbeth, and the inability of most of the characters, including Macbeth himself, to decode the implicit or hidden meaning behind assertions and statements has a decisive impact on the chain of events within the play.

In the fourth scene of Act I, Duncan ponders over the act of treason committed by the erstwhile Thane of Cawdor and laments: "There's no art/ To find the mind's construction in the face:" (I.IV.11-12). Very soon thereafter, in the fifth scene, Lady Macbeth is introduced as reading a letter from Macbeth informing her about the latest developments-about the prophecies of the witches, Duncan's bestowal of a new title upon him, and, most importantly, the king's impending visit to their castle. Now, one must notice that Lady Macbeth makes her entry into the play reading (or rather following the trails) about the witches; thus, like Macbeth, as seen earlier, the connection between them is established at the very outset. The words Macbeth uses to describe the witches are also significant: "They met me in the day of success; and I have/ learn'd 
by the perfect'st report, they have more in/ them than mortal knowledge" (I.V.1-3). For Macbeth, these weird sisters know things that often lie concealed beneath the veneer of words. That they speak precisely of what is necessary at a particular moment and conceal more than what they reveal only serve to confound the listeners (both within and outside the play) whose appetite for more clarification grows by the moment.

It may be argued that through the medium of the letter, it is as if the witches have transferred the agency of action to Lady Macbeth who takes it upon herself to take forward the unfinished business to its completion when she waits impatiently for Macbeth to reach home so that (in her words): "I may pour my spirits in thine ear,/ And chastise with the valour of my tongue" (I.V.26-27). Her resolve to use her power of language to enter into the soul of Macbeth via his ears is an extension of the linguistic competence of the weird sisters and, also possibly, a reference to the subversive tendencies of language employed by witchcraft to destabilize the balance of power exercised by the royal authority. Eagleton (quoted in Dollimore lv) reveals the agency of the witches in shrewd and diabolical language play when he states that, "their [the witches'] riddling, ambiguous speech ... promises to subvert this [hierarchical social] structure: their teasing word-play infiltrates and undermines Macbeth from within, revealing in him a lack which hollows his being into desire. The witches signify a realm of non-meaning and poetic play which hovers at the work's margins." The witches converse among themselves and with others in a linguistic register that resists easy understanding; however, it is at one's own peril that their speeches would be dismissed as mere gibberish. The impact of their words pervades through the thoughts and actions of the characters of the play, both those who have encountered them and the ones who would not (as Lady Macbeth herself). Besides, as Greenblatt notes concerning the threat posed by the devil with whose powers the witches are supposedly invested, "The devil's 
goal is the ruin not of a tiny hamlet but of a whole kingdom, and hence his principal target is ... God's own representative on earth, the king" (345). He further says that, "If Satan's scholars only spoke lies, their master would soon lose credit, and if they straightforwardly told the truth, they could scarcely do the devil's work. So their prognostications are 'always doubtsome, as his Oracles were'" (345-346). The very fact that the witches often stop short of suggesting the obvious is also an act of self-empowerment for them. It is owing to the opacity of their words that the characters who hear them can never be entirely sure of what they mean. The act of decoding on the part of the listeners often results in exposing their strengths or frailties of character; they end up being responsible for their actions and the consequences.

Therefore, in instigating her husband to murder the king, Lady Macbeth is not merely attempting to force into fruition what, according to her, "fate and metaphysical aid doth seem/ To have thee crown'd withal" (I.V.29-30), but also initiating a chain of events that would eventually lead to anarchy and misrule throughout the whole kingdom. This is somewhat akin to what Guy Fawkes along with his cohorts intended to do, all because the king stood as an impediment towards the fulfillment of their personal/parochial ambitions. And even Lady Macbeth is aware of the subversive potential of her ambitions and therefore invokes the spirits that harbor murderous intentions (possibly, the same source of power that empowers the witches) to 'unsex her', i.e., to denude her of her feminine attributes, so that what fills her from head to toe is the capability to execute acts of "direst cruelty" (I.V.43). The agency of witches, therefore, remains pervasive throughout the whole narrative of the play; they are never absent from active action, and not even Banquo, with his sworn allegiance to the king, can escape the tremors of conscience within him as he prays: "merciful Powers!/ Restrain in me the cursed thoughts that nature/ Gives way to in repose!" (II.I.7-9). Banquo's fears are however not unfounded because soon after 
Macbeth, following the words of the witches and his wife, goes ahead with the bloody business of murdering the king. In the famous 'dagger scene' that precedes the act, Macbeth invokes the witches as he announces: "Witchcraft celebrates/ Pale Hecate's off'rings" (II.I.51-52). In a way, for Macbeth, the act of murder also becomes a kind of his ritualistic initiation into the deep, dark, and evil world of hell. The act of murdering Duncan is something that Macbeth commits against the natural flow of things; he tries to force the matter towards its conclusion rather than waiting for it to take its course. This is precisely how and when Macbeth, along with his wife, succumbs irrevocably to the machinations of the weird sisters, henceforth never to find peace in their lifetime.

In the moments immediately following the dreadful and sickening scene of Duncan's murder, as both Macbeth and his wife are deliberating over clearing themselves of the filthy deed and coming to terms with reality, a loud knocking at the gate of the castle is heard. Responding to the knocking, the porter, who is guarding the gate, wakes up in a drowsy state and imagines himself as the gatekeeper of Hell and welcoming new visitors to the realm of darkness. As the knocking increases, he refers to one of the visitors as: "Knock, knock. Who's/ there i'th'other devil's name?-Faith, here's an/ equivocator, that could swear in both the scales/ against either scale; who committed treason enough/ for God's sake, yet could not equivocate to heaven:/ O! come in, equivocator" (II.III.7-12). By the term 'equivocator', Shakespeare here was clearly reminding his audience of the Jesuit priest Garnet, and a conscious reference to the immediately preceding act of Macbeth was established. Because even though Macbeth will be successful initially in preventing any hint of suspicion falling upon himself or upon his wife, the crime shall not lie concealed much longer and, as one shall see, he will by himself fail to cover up his inner 
guilt and culpability; in other words, Macbeth, even then, following his act of murder, had realized that he would not be able to 'equivocate to heaven.'

Soon after he ascends to the throne of England for being the nearest kinsman to Duncan, Macbeth's anxiety and uneasiness shift to Banquo, as he remembers the prophecies of the weird sisters to the latter, whom they hailed as a "father to a line of kings" (III.I.59) and upon the head of the former placed a "fruitless crown" (III.I.60) and a "barren sceptre" (III.I.61) in his hand, with none of his sons succeeding him to the throne. Therefore, he commissions two hired assassins to waylay Banquo and his son, Fleance, and kill them both in the process. However, what Macbeth errs in recognizing here is precisely that the agency that made him Glamis, Cawdor, and King in the first place shall act likewise in the case of his opponents too. By deliberately attempting to fight against his fate, Macbeth undermines the very authority that has empowered him so far. In this context, one can argue that if the act of killing Duncan robs Macbeth of his morality, his subsequent act of killing Banquo robs him of his sanity, as it becomes evident from how he reacts upon witnessing the ghost of Banquo (visible only to him) taking his place (very suggestively) among the guests in the banquet scene. This is the scene where Macbeth's inner guilt and his active hand behind the killing of Duncan and Banquo are exposed, as he confesses: "blood will have blood:/ Stones have been known to move, and trees to speak;/ Augures, and understood relations, have/ ... brought/ forth/ The secret'st man of blood" (III.IV.121-125).

In a desperate attempt to once and for all put an end to his fears and misgivings that have taken tangible shapes in his imagination now, Macbeth decides to visit the weird sisters to find out what lies ahead of him: "More shall they speak; for now I am bent to know,/ By the worst means, the worst" (III.IV.133-134). What equates his earlier and the present meeting with the 
witches is that on both these occasions he has just emerged from committing a "bloody deed;" whereas on the earlier occasion, he was engaged in legitimate killing in the name of the King, the present instance has seen the reversal of dynamics - the goodness that he embodied then has now deteriorated into a monstrosity - he is now the 'most disloyal traitor' himself. Macbeth is so steeped in blood now that he can wade no more in the quagmire without the agency of the witches to guide him. Accordingly, he meets the witches as they are just done with conjuring a charm by mixing miscellaneous ingredients into a boiling cauldron. He addresses them as "secret, black, and midnight hags" (IV.I.47) and commands them to respond to his queries. However, in the process of putting them forward, he also lists the myriad of mischief committed by them to confound the humans, again hinting at their agency manifesting itself through various natural events like the raising and turning of the winds and waves in the seas, displacing the corn from one blade to another, blowing down trees, bending down castles and palaces_-all examples resonating very well with the imagination of James I and the audience watching the play. It was a common practice during that period to attribute such happenings to the agency of the malevolent witches, and such cases were often posited as charges against which women suspected of witchcraft were apprehended and punished for their supposed crimes. However, as far as King James was concerned, his attitude towards witchcraft had undergone marked changes by the close of the sixteenth century and subsequently when he assumed the throne of England in 1603. The composition of Daemonologie in 1597 could also be seen as an attempt on his part to undertake a deeper investigation into the practice of witchcraft. ${ }^{6}$

In an ironic twist of events, Macbeth, the king and the protector of the people, is himself invoking the aid of witchcraft to secure his throne against the very prophecies that made him king in the first place. The witches do not speak by themselves this time. Instead, they conjure up 
three apparitions that one by one predicts what lies in the future for Macbeth. The three apparitions speak in highly suggestive tones and, to an extent, also indulge in equivocation. The first apparition — an armed head—representing symbolically the head of Macbeth that would eventually be cut off and, with a sense of foreboding, it warns him: "Macbeth! Macbeth! Macbeth! Beware Macduff;/ Beware the Thane of Fife" (IV.I.71-72). The second apparition—a bloody child - is that of Macduff, and symbolizes the very answer to the warning it issues Macbeth: "Be bloody, bold, and resolute: laugh to scorn/ The power of man, for none of woman born/ Shall harm Macbeth" (IV.I.79-81). The third apparition is most suggestive—a child crowned, with a tree in his hand-he represents the royal prince Malcolm who will nullify the prediction made by it: "Macbeth shall never vanquish'd be, until/ Great Birnam wood to high Dunsinane hill/ Shall come against him" (IV.I.92-94).

Macbeth is not yet satisfied, and he has an urgent question: "shall Banquo's issue ever/ Reign in this kingdom?" (IV.I.103-104), to which the witches present before him a show of eight kings, with the last one holding a glass in his hand where appears images of many more to come. The first king in the witches' pageant show resembles Banquo, the second one again is like the first, and this goes on. This show also presented Shakespeare with an opportunity to establish the lineal connection from Banquo's immediate successor till the present one witnessing the playwithin-the-play in the theatre. The witches then take leave with a highly resonant speech that could as well speak for the efforts of the King's Men to please James I who must have been amazed by the theatrical performance they have mounted for his amusement: "Ay, Sir, all this is so:-but why/ Stands Macbeth thus amazedly?_/ Come, sisters, cheer we up his sprites,/ And show the best of our delights./ I'll charm the air to give a sound,/ While you perform your antic round;/ That this great King may kindly say,/ Our duties did his welcome pay" (IV.I.125-132). 
The witches dance and then vanish for the one last time. And possibly, with their departure, they take away all their charms and powers and leave behind only words for the 'inhabitants of the earth' to decode and understand. In other words, the last speech of the witches is another instance of equivocation where they wrap up their rendezvous with the king by rendering him services (in the form of titles and positions) that he most desired for, and now they are leaving him all to himself to reap the harvest of his misdeeds. Interestingly, the witches are only visible to Macbeth this time, as proven by his query to immediately approaching Lenox if he saw the weird sisters to which the latter replies in the negative.

Macbeth finally realizes his utter folly in believing in the agency of the witches as he confesses: "Infected be the air whereon they ride;/ And damn'd all those that trust them!" (IV.I.138-139). However, the realization comes to him way too late. He has already waded through a lot of blood, and, in acts of desperation, has committed many more bloody acts before finally being confronted by his own fate. When the messenger informs him that "[t]he wood began to move" (V.V.34), he gets convinced of the falsity of the "equivocation of the fiend" (V.V.43), and resolves to confront the attackers head-on. And finally, as he fights with Macduff, he tells him about his charmed life to which the latter reveals that "Macduff was from his mother's womb/ Untimely ripp'd" (V.VIII.15-16), and, therefore, he is the man who is destined to kill Macbeth. And as he confronts death in the form of Macduff, Macbeth for the one last time remembers the witches and as he reiterates the cause of his destruction: "be these juggling fiends no more believ'd,/ That palter with us in a double sense;/ That keep the word of promise to our ear,/ And break it to our hope" (V.VIII.19-22). Nevertheless, Macbeth refuses to yield to his fate and vows to fight till the last moment, which he does until he is finally slain. 


\section{Implications}

The death of Macbeth is followed by the restoration of order with Malcolm installed as the new King of Scotland. However, beneath the seeming order, the currents of discontentment and disruptions have not yet been laid to rest as they would not be till the time of the present monarch James I which the king himself and the audience might well have realized. That makes the last scene of the play all the more allusive and significant. Especially crucial again is the agency of the witches here, with all their powers of equivocation not yet tamed to submission as far as the sanctity and security of the royal authority are concerned. One can agree somewhat with Greenblatt when he says: "Macbeth leaves the weird sisters unpunished but manages to implicate them in a monstrous threat to the fabric of civilized life. The genius of the play is bound up with this power of implication, by means of which the audience can never quite be done with them, for they are most suggestively present when they cannot be seen, when they are absorbed in the ordinary relations of everyday life" (354-355). The play continues to bewitch and bedazzle its audience even to this day; the sorcery of the witches seems to influence even the very performance of the play, as is evident from various beliefs and superstitions attached to its history of reception. ${ }^{7}$ The history of Shakespeare in performance, including Macbeth, across various cultures, has added new meaning and significance to the narrative and interpretive dimensions of the plays. The plots and characters, as envisioned by Shakespeare, have often been reimagined and restructured to suit the adaptation of the plays in performance upon foreign shores. As Dennis Kennedy notes, "foreign Shakespeare is more present than ever before, interrogating the idea that Shakespeare can be contained by a single tradition or by a single culture or by a single language. ... In the end Shakespeare doesn't belong to any nation or anybody: Shakespeare is foreign to all of us" (16). 
Moreover, from an Indian perspective, the reading of this play, or rather the whole Shakespearean dramatic corpus, provides interesting insights into the history of its adaptation and reception outside Europe. A year after the first performance of the play, in 1607, a fleet of three ships, namely, the Dragon, the Hector, and the Consent set sail for the East Indies under the command of Captain William Keeling in a voyage sponsored by the East India Company. It is revealed from the pages of Captain Keeling's journal that "two performances of Shakespeare took place aboard the Hector" (Loomba 111). Towards the end of the eighteenth century and throughout the nineteenth century, Shakespeare became a vital component in the propagation of English colonial/cultural superiority over the colonized population in Asia and Africa. Commenting upon the increasing trend of performing Shakespeare in and around Calcutta since the 1770s, Jyotsna Singh notes as to "how the reproduction of the English play-both as a dramatic and literary text-... was crucial in producing a discourse of cultural colonialism-a discourse in which Shakespeare was undoubtedly a privileged signifier" (447). With regards to Macbeth, there were two notable productions of the play in Bengali. Girish Chandra's Macbeth was performed in the last decade of the nineteenth century, and, by that time, Shakespeare was sufficiently indigenized to suit the Indian stage (Sarma 41). The second performance took place in the 1950s when Utpal Dutt produced his Bengali version of Macbeth which was performed before audiences in the remote countryside of Bengal. This rural Bengali version of Macbeth was supposedly closer to the "blood and guts of the Elizabethan theatre" (Singh 455). The journey of Shakespeare in India has come full circle; just like his witches, he refuses to remain ensconced in constructed categories and allows himself to be received and interpreted in myriad and contested ways. Playwrights, translators, audiences, and readers across languages and continents have 
attempted to fashion his aura in terms of their respective sensibilities. And Shakespeare, like his witches, has duly played his part in enabling ever new dramatic conjurations as befitting the tastes and predilections of his diverse readers and audiences across the seas.

To conclude, therefore, like Hamlet's "antic disposition" (Hamlet I.V.180), Iago's “motiveless Malignity" (Coleridge 1050-1051), ${ }^{8}$ and Lear’s "darker purpose” (King Lear I.I.35), Macbeth's "Vaulting ambition" (I.VII.27) provides a window for us readers to similarly frame our responses to the plays. However, just like the witches' mastery of equivocation, we too must not fall prey to take one of these aspects as the 'word of promise'. In many ways through which he made clear, Shakespeare conceived the structure of this play not merely to please the newly enthroned king or to enthrall the audience with supernatural spectacles, but also to bring to the surface the hidden inconsistencies and contradictions that defined the behavior of the king and his people alike. And when the characters in the last scene of the play hail Malcolm as the king of Scotland, the audience would surely have recognized the fact that, in the course of the single play, there have been three kings of Scotland—Duncan, Macbeth, and now Malcolm—which exposes the brittleness and instability of purpose within the royal order. Interestingly, the other son of Duncan, Donalbain, remains absent from the action after he escapes to Ireland following the murder of his father, and one does not get to hear anything about him even after the restoration of order. Is he going to be the new target of the witches or the malevolent forces of nature that seek to destabilize any semblance of order created by the humans? Shakespeare did not bother to answer this and many other similar questions at the end of the play, for it was through these unresolved questions that his agency of equivocation was made apparent to his contemporary audience and future readers like us at the moment. 


\section{Endnotes}

1. Hattaway states the political implications surrounding the composition and the staging of the play Macbeth in a very concise manner: "Macbeth assassinated his way to the throne of Scotland: his comrade in arms Banquo, whose rectitude contrasts with that of the hero, was ancestor to King James (before whom the play may have been performed in 1606) and bore testimony to his descendant's moral legitimacy. (James had escaped assassination in the Gunpowder Plot of 1605)" (108). These connections will be explored at length in the course of this study.

2. In his Introduction to the Arden Shakespeare edition of Macbeth, Muir notes, "Yet there is no play which puts so persuasively the contrasting good. Shakespeare makes Duncan venerable and saintly, Malcolm an image of perfection, Macduff a righteous avenger.... The contrast between light and darkness symbolizes a general contrast between good and evil, devils and angels, hell and heaven. The disease images clearly reflect both the sin which is a disease and Macbeth himself who is the disease, from which Scotland suffers" (xliv-xlv).

3. In Sophocles' King Oedipus, it is Apollo's oracle which prophesies that Oedipus is destined one day to kill his father and marry his mother that causes Laius, his father, to order for his execution. However, as it happens, baby Oedipus is not killed but handed over to a Corinthian shepherd who in turn brings it to his king. When he grows up, Oedipus gets to know, from Apollo's ministers, about the terrible curse of his birth, and, therefore, leaves Corinth for the fear of the prophecies coming true, only to end up returning to Thebes, his birthplace. On his way, he encounters Laius and unknowingly 
kills him, and, upon reaching Thebes, liberates the city from a monster. In the absence of their king, the Theban citizens hail him as their savior and install him as their new king. Oedipus marries Jocasta, the widowed queen of Laius, and, in this way, fulfills the prophecies of Apollo.

4. In her chapter Shakespeare and the Politics of Superstition, Susan James notes that "Macbeth was first performed shortly after the accession of James I, and many critics have speculated about the local political meanings that may have been placed on it. Perhaps one of these would have derived from the fact that James had himself believed that he was under attack from witches in league with the devil.... [S]ome members of Shakespeare's audience would have been aware of James's earlier obsession, and of the Demonologie he had written by way of a reply to Reginald Scot. Perhaps, then, the play would partly have been understood as the representation of a disastrous course of events from which James had had the strength of character to pull back, and thus as a reminder of his virtue" (95).

5. A detailed summary of the incident could be accessed from https://www.parliament.uk/about/livingheritage/evolutionofparliament/parliamentaryauthority/the-gunpowder-plot-of-1605/.

6. In her stimulating essay entitled "The Malleus Maleficarum and King James: Defining Witchcraft", Elizabeth Mack undertakes a comparative study between Malleus Maleficarum (a medieval treatise on witchcraft composed by Heinrich Kramer and printed in 1487) and the Daemonologie of James I (181). She notes that there occurred a 
significant rise in witch prosecutions around 1560 (182), and both these texts addressed the skeptics who had questioned the existence of witchcraft, and, in response, described the way and means to prosecute witches (183). King James I wrote about two kinds of witches: the ones who acted upon themselves through their worship of the devil, and the other ones who acted upon other people (184). He considered witchcraft to be a serious crime, and he wished to educate his subjects on the dangers and perils of this vile practice, as against Kramer who openly advocated in support of witch-hunting (185). Even though his ideas and sources referred back to earlier treatises on demonology, yet his approach to the subject was more humane and he did not consider women as naturally inclined to the sin of witchcraft (187).

7. "Macbeth is also a play whose stage history has been shrouded in mystery and superstition. So strong is the belief among actors that the play carries a magic of its own that taboos still exist today against speaking the name 'Macbeth' in the theater (outside the play's text itself). Those who break the rules must perform time-honored rituals to undo the curse: leave the room, turn around three times, spit, knock on the door three times and beg to be readmitted." (“A Look Back at Macbeth in Performance”)

8. "Coleridge's well-known remarks on Iago are provoked by the villain's final speech of Act 1. Responding to lines 1.3.380-404, Coleridge writes:

The last Speech, the motive-hunting of motiveless Malignity - how awful! In itself fiendish - while yet he was allowed to bear the divine image, too fiendish 
for his steady View. - A being next to Devil - only not quite Devil - \& this Shakespear has attempted - executed - without disgust, without Scandal!

Coleridge seems to be suggesting that Iago's wickedness is without clear provocation within the logic of the play. His villainy lacks a clear motive, but arises from sheer delight in the suffering of others. This makes Iago 'fiendish' like the 'devil', yet disconcertingly human." (https://www.bl.uk/collection-items/coleridges-annotated-copy-of-shakespeare)

\section{Works Cited}

Bate, Jonathan. Soul of the Age: A Biography of the Mind of William Shakespeare. Random House, 2010.

Bertens, Hans. "Cultural Materialism.” Oxford Bibliographies. https://www.oxfordbibliographies.com/view/document/obo-9780190221911/obo9780190221911-0091.xml. Accessed 26 June 2021.

Bevington, David. "Macbeth." Encyclopedia Britannica. https://www.britannica.com/topic/Macbeth-by-Shakespeare. Accessed 26 June 2021.

Bloom, Harold, editor. William Shakespeare's Macbeth (New Edition). Bloom's Literary Criticism, 2010.

Coleridge, Samuel Taylor. The Dramatic Works of William Shakespeare: With Explanatory Notes. To Which Is Added, a Copious Index to the Remarkable Passages and Words, by Samuel Ayscough. London, 1807, https://www.bl.uk/collection-items/coleridgesannotated-copy-of-shakespeare. Accessed 26 June 2021. 
CST Education Department. “A Look Back at Macbeth in Performance.” Short Shakespeare! Macbeth, Chicago Shakespeare Theater on Navy Pier, https://www.chicagoshakes.com/plays_and_events/ssmacbeth2011/ssmacbethperformance-history. Accessed 26 June 2021.

Dollimore, Jonathan. Radical Tragedy: Religion, Ideology and Power in the Drama of Shakespeare and his Contemporaries. $3^{\text {rd }}$ ed., Palgrave Macmillan, 2004.

Eagleton, Terry. William Shakespeare (Rereading Literature Series). Blackwell, 1986, pp. 2-3. Greenblatt, Stephen. Will in the World: How Shakespeare Became Shakespeare. W.W. Norton \& Company, 2005.

Hattaway, Michael. "Tragedy and Political Authority." The Cambridge Companion to Shakespearean Tragedy, edited by Claire McEachern, Cambridge University Press, 2004, pp. 103-122.

Huntley, Frank L. "Macbeth and the Background of Jesuitical Equivocation." PMLA, vol. 79, no. 4, 1964, pp. 390-400. JSTOR, https://doi.org/10.2307/460744. Accessed 26 June 2021. James, Susan. "Shakespeare and the Politics of Superstition." Shakespeare and Early Modern Political Thought, edited by David Armitage, Conal Condren, and Andrew Fitzmaurice, Cambridge University Press, 2009, pp. 80-98.

Kennedy, Dennis. “Introduction: Shakespeare Without His Language.” Foreign Shakespeare: Contemporary Performance, edited by Kennedy, Cambridge University Press, 1993, pp. $1-18$.

Kott, Jan. Shakespeare Our Contemporary. Translated by Boleslaw Taborski, Methuen \& Co. Ltd., 1983. 
Loomba, Ania. "Shakespearian Transformations." Shakespeare and National Culture, edited by John J. Joughin, Manchester University Press, 1997, pp. 109-141.

Mack, Elizabeth. "The Malleus Maleficarum and King James: Defining Witchcraft." Voces Novae, vol. 1, no. 9, 2009, pp. 181-203, https:/digitalcommons.chapman.edu/vocesnovae/vol1/iss1/9. Accessed 26 June 2021.

Maguire, Larrie E. Studying Shakespeare: A Guide to the Plays. Blackwell Publishing Ltd., 2004.

Malloch, A.E. "Father Henry Garnet's Treatise of Equivocation.” Recusant History, vol. 15, no. 3, 1980, pp. 387-395, https://doi.org/10.1017/S0034193200000807. Accessed 26 June 2021.

Muir, Kenneth. Introduction. Macbeth, edited by Muir. The Arden Shakespeare. Routledge, 1995, pp. xiii-lxv.

"New Historicism." Glossary of Poetic Terms, Poetry Foundation, https://www.poetryfoundation.org/learn/glossary-terms/new-historicism. Accessed 26 June 2021.

Russell, Willy. Education Rita, edited by Richard Adams. Longman, 1985.

Sarma, Dhurjjati. "Reinterpreting the'Bard': Shakespearean Performances in India and (East) Germany.” Space and Culture, India, vol. 1, no. 2, 2013, pp. 35-43, https://doi.org/10.20896/saci.v1i2.29. Accessed 26 June 2021.

Shakespeare, William. Macbeth, edited by Kenneth Muir. The Arden Shakespeare. Routledge, 1995.

Shakespeare, William. Othello, edited by E.A.J. Honigmann. The Arden Shakespeare. Thomson Asia Pte. Ltd., 2002. 
Shakespeare, William. King Lear, edited by R.A. Foakes. The Arden Shakespeare. Thomson Asia Pte Ltd., 2003.

Shakespeare, William. Hamlet, edited by Harold Jenkins. The Arden Shakespeare. Thomson Asia Pte Ltd., 2004.

Singh, Jyotsna. "Different Shakespeares: The Bard in Colonial/Postcolonial India." Theatre Journal, vol. 41, no. 4, 1989, pp. 445-458. JSTOR, https://www.jstor.org/stable/3208007. Accessed 26 June 2021.

Smith, Emma. Macbeth: Language and Writing. Bloomsbury Publishing, 2013. Sophocles. The Theban Plays: King Oedipus, Oedipus at Colonus, Antigone. Translated by E.F. Watling, Penguin Books, 1974.

"The Gunpowder Plot.” UK Parliament, https://www.parliament.uk/about/livingheritage/evolutionofparliament/parliamentaryauthority/the-gunpowder-plot-of-1605. Accessed 26 June 2021.

\section{Bionote}

Dhurjjati Sarma is an Assistant Professor in the Department of Modern Indian Languages and Literary Studies, Gauhati University, Assam. He was earlier a Production Editor at SAGE Publications, New Delhi, and, before that, a Research Fellow in North East India Studies at the Indira Gandhi National Centre for the Arts (IGNCA), New Delhi. He is presently engaged in teaching and research in literary history, comparative literature, and cultural studies. His writings have been published under Palgrave Macmillan and in journals like Space and Culture, India and Margins: A Journal of Literature and Culture. He is presently working on a critical history of Assamese literature. He can be reached at dhurjjati.sarma@gmail.com

ORCID ID: https://orcid.org/0000-0002-3808-0152 


\section{Open Access:}

This article is distributed under the terms of the Attribution-NonCommercial 4.0 International (CC BY-NC 4.0) (https://creativecommons.org/licenses/by/4.0/) which permits any use, reproduction and distribution of the work without further permission provided the original work is attributed as specified on the Transcript: An e-Journal of Literary and Cultural Studies.

For more information log on to http:/thetranscript.in/

\section{Conflict of Interest Declaration:}

The author declared no potential conflicts of interest about the research, authorship, and publication of this article.

(C) Author 